\title{
High-performance Pt catalysts supported on hierarchical nitrogen-doped carbon nanocages for methanol electrooxidation
}

\author{
Xiangfen Jiang a,b, Xuebin Wang a, Liming Shen a , Qiang Wu ${ }^{a}$, Yangnian Wang a, Yanwen Ma ${ }^{a}$, \\ Xizhang Wang ${ }^{\mathrm{a}, *}$, Zheng $\mathrm{Hu}^{\mathrm{a}, \#}$ \\ ${ }^{a}$ Key Laboratory of Mesoscopic Chemistry of MOE, School of Chemistry and Chemical Engineering, Nanjing University, Nanjing 210093, Jiangsu, China \\ b International Center for Materials Nanoarchitectonics (MANA), National Institute for Materials Science (NIMS), Tsukuba 3050044, Japan
}

\section{A R T I C L E I N F O}

\section{Article history:}

Received 30 March 2016

Accepted 18 April 2016

Published 5 July 2016

\section{Keywords:}

Methanol oxidation

Fuel cells

Platinum catalyst

Hierarchical nitrogen-doped carbon

nanocages

High performance

\begin{abstract}
A B S T R A C T
Hierarchical nitrogen-doped carbon nanocages (hNCNC) with large specific surface areas were used as a catalyst support to immobilize Pt nanoparticles by a microwave-assisted polyol method. The $\mathrm{Pt} / \mathrm{hNCNC}$ catalyst with $20 \mathrm{wt} \%$ loading has a homogeneous dispersion of Pt nanoparticles with the average size of $3.3 \mathrm{~nm}$, which is smaller than 4.3 and $4.9 \mathrm{~nm}$ for the control catalysts with the same loading supported on hierarchical carbon nanocages ( $\mathrm{hCNC}$ ) and commercial Vulcan XC-72, respectively. Accordingly, $\mathrm{Pt} / \mathrm{hNCNC}$ has a larger electrochemical surface area than $\mathrm{Pt} / \mathrm{hCNC}$ and Pt/XC-72. The Pt/hNCNC catalyst exhibited excellent electrocatalytic activity and stability for methanol oxidation, which was better than the control catalysts. This was attributed to the enhanced interaction between Pt and hNCNC due to nitrogen participation in the anchoring function. By making use of the unique advantages of the hNCNC support, a heavy Pt loading up to $60 \mathrm{wt} \%$ was prepared without serious agglomeration, which gave a high peak-current density per unit mass of catalyst of $95.6 \mathrm{~mA} / \mathrm{mg}$ for achieving a high power density. These results showed the potential of the Pt/hNCNC catalyst for methanol oxidation and of the new hNCNC support for wide applications.

(C) 2016, Dalian Institute of Chemical Physics, Chinese Academy of Sciences. Published by Elsevier B.V. All rights reserved.
\end{abstract}

\section{Introduction}

Direct methanol fuel cells (DMFCs) have attracted considerable attention as ideal candidates for automotive and portable applications due to the advantages of high energy conversion efficiency and ability to be easily handled [1]. The major obstacles to DMFC practical application are the low catalytic performance, high cost, and poor durability of the noble metal catalysts [2]. A catalyst support with a large surface area and stable structure will lead to high dispersion, high utilization and stability of Pt nanoparticles and overcome these obstacles [3]. Carbon materials with high specific surface areas (SSAs) are good supports in DMFCs due to their high electrical conductivity, corrosion resistance, and low cost $[3,4]$. Apart from commercial activated carbon supports, e.g., Valcan XC-72 [5], which usually engulf a lot of Pt in their primary micropores and thus cause some catalytic activity loss, several novel carbon nanomaterials such as carbon nanotubes [6], carbon nanofibers

\footnotetext{
*Corresponding author. Tel/Fax:+86-25-89683696; E-mail: wangxzh@nju.edu.cn

\# Corresponding author. Tel/Fax: +86-25-89686015; E-mail: zhenghu@nju.edu.cn

This work was supported by the National Natural Science Foundation of China $(21473089,51232003,21373108,51571110,21573107)$, the National Basic Research Program of China (973 Program, 2013CB932902), Suzhou Science and Technology Projects (ZXG2013025), and Changzhou Science and Technology Projects (CE20130032). This work was also supported by a Project Funded by the Technology Support Priority Academic Program Development of Jiangsu Higher Education Institutions.
}

DOI: 10.1016/S1872-2067(15)61117-2 | http://www.sciencedirect.com/science/journal/18722067 | Chin. J. Catal., Vol. 37, No. 7, July 2016 
[7], carbon nanocoins [8] and graphene [9] have also been explored. Owing to the surface inertness, surface modification are usually used to introduce anchoring sites, e.g., by acid oxidation and covalent grafting $[10,11]$. However, these methods usually involve complex processes and inevitably damage the structural, mechanical, and electrical properties. Alternatively, in situ nitrogen doping into the carbon matrix during growth can introduce chemically active sites for anchoring metal and metal oxide nanoparticles [12-18]. Our studies indicated that Pt-based nanoparticles could be easily and uniformly immobilized on N-doped carbon nanotubes (NCNTs), and these showed enhanced electrocatalytic performance for methanol oxidation and oxygen reduction [13-15]. However, the SSA of the NCNTs is usually not large enough, as it is only $200 \mathrm{~m}^{2} / \mathrm{g}$. Very recently, by an in situ MgO template method, we reported unique 3D hierarchical carbon-based nanocages that featured high SSAs up to $1400 \mathrm{~m}^{2} / \mathrm{g}$ and good conductivity [19-23], which exhibited excellent electrochemical performances. By using hierarchical $\mathrm{N}$-doped carbon nanocages (hNCNC) as a new support, here we report the high dispersion of a Pt electrocatalyst on hNCNC made by a modified microwave-assisted polyol method. The constructed Pt/hNCNC demonstrated excellent electrochemical activity and good stability for methanol oxidation, which were superior to those of their counterparts supported on carbon nanocages and commercial Vulcan XC-72. Both the strong interaction between $\mathrm{Pt}$ and hNCNC and the excellent dispersion of Pt by nitrogen incorporation were responsible for the enhanced performance in methanol electrocatalytic oxidation. This illuminates the application of hNCNC in the field of DMFCs.

\section{Experimental}

\subsection{Construction of the Pt-based catalysts}

hNCNC was prepared by the in situ MgO template method developed recently by our group [20,21], which is characterized by co-existing micro-meso-macropores, good conductivity, and a large SSA generally up to $1400 \mathrm{~m}^{2} / \mathrm{g}$. Briefly, basic magnesium carbonate ( $4 \mathrm{~g}$ ) was placed in a quartz tube and heated to $900{ }^{\circ} \mathrm{C}$. Then $1.8 \mathrm{~mL}$ pyridine was introduced into the reactor at the feeding rate of $60 \mu \mathrm{L} / \mathrm{min}$ by a syringe pump. Sequentially, the $\mathrm{MgO}$ template was removed by $1 \mathrm{~mol} / \mathrm{L} \mathrm{HCl}$ aqueous solution. Finally, hNCNC with 8 at\% nitrogen doping was obtained after washing repeatedly with deionized water and drying at $110{ }^{\circ} \mathrm{C}$. Pt particles were supported on hNCNC by a modified microwave-assisted polyol process [24]. Typically, $25.0 \mathrm{mg}$ hNCNC was ultrasonically dispersed in $50.0 \mathrm{~mL}$ ethylene glycol (EG). Then $1.0 \mathrm{~mL} \mathrm{H}_{2} \mathrm{PtCl}_{6} / \mathrm{EG}$ solution $(7.5 \mathrm{mg}$ $\mathrm{Pt} / \mathrm{mL} \mathrm{EG}$ ) and $0.25 \mathrm{~mL} \mathrm{NaOH} / \mathrm{EG}$ solution ( $0.2 \mathrm{~mol} / \mathrm{L})$ were dropped into the suspension under magnetic stirring. After irradiating with a domestic microwave oven $(800 \mathrm{~W})$ for $100 \mathrm{~s}$, Pt/hNCNC with a nominal loading of 23 wt $\%$ was obtained after filtrating, rinsing, and drying under vacuum for $12 \mathrm{~h}$. For comparison, hierarchical carbon nanocages (hCNC) from a benzene precursor and Valcan XC-72 were also used as the support to prepare $\mathrm{Pt} / \mathrm{hCNC}$ and $\mathrm{Pt} / \mathrm{XC}-72$ in a similar way.

\subsection{Characterization}

The structure and composition of the catalysts were characterized by high resolution transmission electron microscopy (HRTEM, JEM-2100 operating at $200 \mathrm{kV}$ ), scanning electron microscopy (SEM, Hitachi S4800), X-ray diffraction (XRD, Philips X'pert Pro X-ray diffractometer), and X-ray photoelectron spectroscopy (XPS, ULVAC-PHI INC, PHI 5000 VersaProbe, Al $K_{\alpha}$ ). Thermogravimetry (TG, NETZSCH STA449F3) was carried out in air flow at a rate of $10.0^{\circ} \mathrm{C} / \mathrm{min}$. $\mathrm{N}_{2}$ adsorption isotherms were measured on Micromeritics ASAP 2020 at $-196{ }^{\circ} \mathrm{C}$ with the specimens degassed at $300{ }^{\circ} \mathrm{C}$ for $4 \mathrm{~h}$.

\subsection{Electrochemical measurement}

The electrochemical performances were characterized by a CHI 760C workstation (CH Instrument, Inc.) with a three-electrode system at $25^{\circ} \mathrm{C}$. $\mathrm{Ag} / \mathrm{AgCl}$ and a platinum thread served as the reference and counter electrodes, respectively. The work electrode was a thin film electrode with the catalyst casted on a glassy carbon disk of $3.0 \mathrm{~mm}$ in diameter. Typically, a suspension of catalyst $(4.0 \mathrm{mg} / \mathrm{mL})$ was prepared by ultrasonically dispersing $2.0 \mathrm{mg}$ catalyst in $400 \mu \mathrm{L}$ ethanol/water solution $(1 / 2, \mathrm{~V} / \mathrm{V})$ and $100 \mu \mathrm{L}$ Nafion solution (5 wt\% Nafion, Alfa Aesar). Then the $10 \mu \mathrm{L}$ suspension was dropped onto the glassy carbon disk to construct a thin film electrode. Cyclic voltammetry (CV) of hydrogen electrochemical adsorption was measured in $\mathrm{N}_{2}$-saturated $0.5 \mathrm{~mol} / \mathrm{L} \mathrm{H}_{2} \mathrm{SO}_{4}$ solution between -0.23 and $1.0 \mathrm{~V}$ at a scan rate of $50 \mathrm{mV} / \mathrm{s}$. CO stripping CV was measured in $0.5 \mathrm{~mol} / \mathrm{L} \mathrm{H}_{2} \mathrm{SO}_{4}$ solution after $\mathrm{CO}$ bubbling for $15 \mathrm{~min}$ between 0 and $1.25 \mathrm{~V}$ at a scan rate of $10 \mathrm{mV} / \mathrm{s}$. The electrocatalytic CV for methanol oxidation was performed in $1.0 \mathrm{~mol} / \mathrm{L}$ methanol and $0.5 \mathrm{~mol} / \mathrm{L} \mathrm{H}_{2} \mathrm{SO}_{4}$ solution in the potential range of $0-1.0 \mathrm{~V}$ at a scan rate of $50 \mathrm{mV} / \mathrm{s}$. The stability of the catalysts was evaluated by chronoamperometry at $0.60 \mathrm{~V}$ for $2000 \mathrm{~s}$.

\section{Results and discussion}

Fig. 1 displays SEM and TEM images of Pt/hNCNC, Pt/hCNC and Pt/XC-72. Pt particles were homogenously immobilized on hNCNC with the average size of $3.3 \mathrm{~nm}$, which was slightly smaller than $4.3 \mathrm{~nm}$ for Pt/hCNC and $4.9 \mathrm{~nm}$ for Pt/XC-72, which indicated the better dispersion on hNCNC than on hCNC and XC-72 due to the nitrogen participation as expected [13-15]. The interplanar spacing of $0.226 \mathrm{~nm}$ corresponded to $d_{111}$ of (fcc) Pt (PDF 88-2343). The three catalysts were further characterized by TG and XRD. The results are presented in Fig. 2. The Pt loadings were obtained to be 21.6, 21.2, and 19.0 wt $\%$, respectively, close to the $23.1 \mathrm{wt} \%$ Pt nominal value (Fig. 2(a)). The Pt particles were assigned to (fcc) Pt (PDF 88-2343). The $d_{111}$ spacing of the peaks at $39.8^{\circ}$ (Fig. 2(b)) was in agreement with the TEM fringes (Fig. 1).

XPS spectra of the catalysts are shown in Fig. 3. The Pt $4 f$ peaks can be deconvoluted into three $\mathrm{Pt}$ species, i.e., $\mathrm{Pt}(0)$ (71.2 eV), Pt(II) (72.4 eV) and Pt(IV) (74.4 eV) for Pt $4 f_{7 / 2}$ [25], with the corresponding ratio of $60.3: 30.8: 8.9$ for Pt/hNCNC. Thus, 

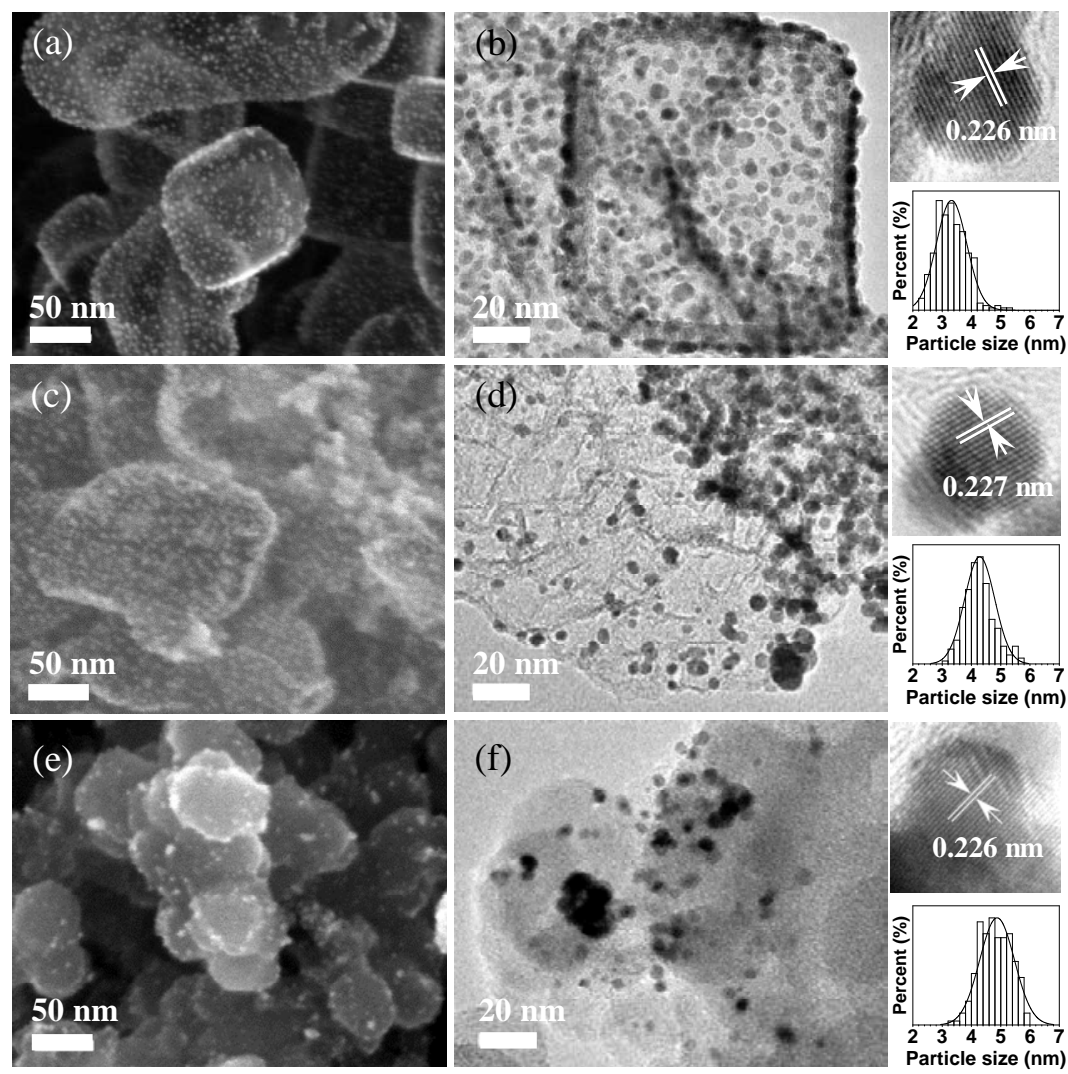

Fig. 1. SEM and TEM images of Pt/hNCNC (a,b), Pt/hCNC (c,d), and Pt/XC-72 (e,f). The inserts are the corresponding HRTEM images and particle size histograms from $400 \mathrm{Pt}$ nanoparticles.
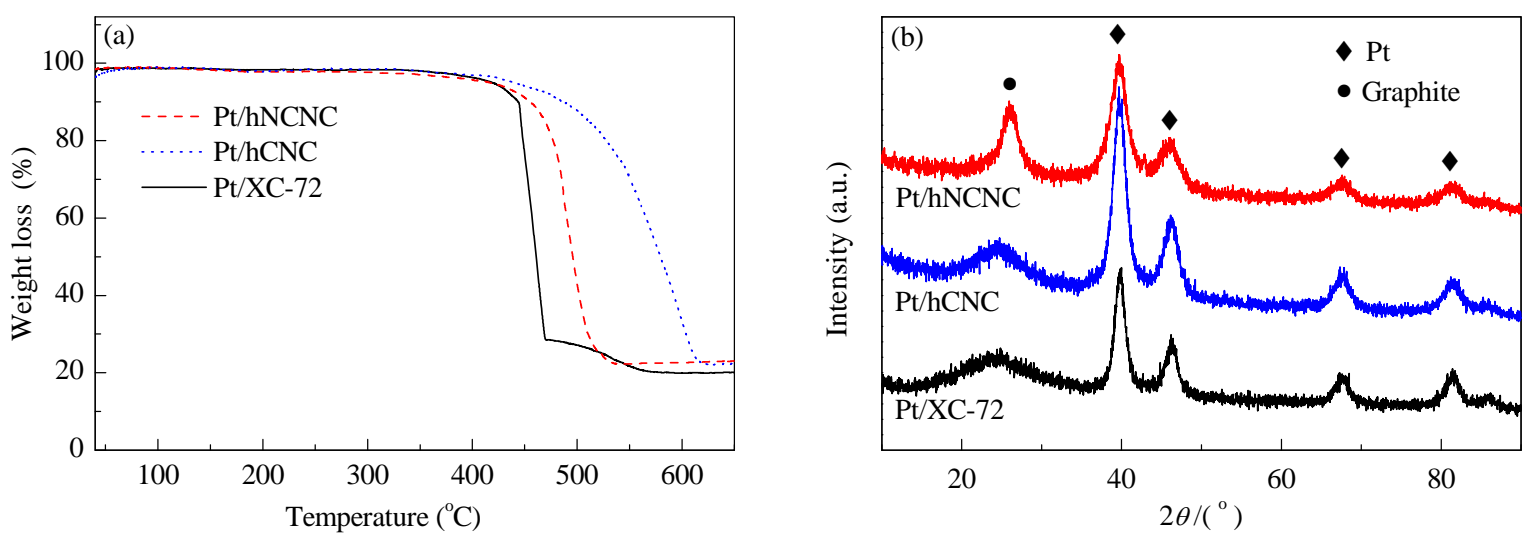

Fig. 2. TG curves (a) and XRD patterns (b) of Pt/hNCNC, Pt/hCNC, and Pt/XC-72.

the Pt species exist predominantly as metallic $\mathrm{Pt}(0)$ in the three catalysts (Fig. 3(b)-(d)). The total Pt contents were characterized to be 23.0, 22.3 and $20.1 \mathrm{wt} \%$ in Pt/NCNC, Pt/hCNC and $\mathrm{Pt} / \mathrm{XC}-72$, respectively, which were close to the TG analysis results (Fig. 2(a)).

The electrochemical surface area (ECSA) of Pt in Pt/hNCNC, $\mathrm{Pt} / \mathrm{hCNC}$ and Pt/XC-72 were measured by CV tests of hydrogen adsorption and $\mathrm{CO}$ stripping, as illustrated in Fig. 4. ECSAн were obtained to be $45.6,34.2$ and $24.2 \mathrm{~m}^{2} / \mathrm{g}$, and ECSAco to be 50.7 , 34.3 and $21.8 \mathrm{~m}^{2} / \mathrm{g}$, respectively. Both results showed the ECSA order of $\mathrm{Pt} / \mathrm{hNCNC}>\mathrm{Pt} / \mathrm{hCNC}>\mathrm{Pt} / \mathrm{XC}-72$, which was consistent with the size order of the Pt particles from TEM and
XRD characterization (Fig. 1, Fig. 2(b)). These results clearly indicated the $\mathrm{Pt}$ dispersion was in the order of $\mathrm{Pt} / \mathrm{hNCNC}>$ Pt/hCNC > Pt/XC-72.

The electrocatalytic activity and stability of the catalysts for methanol oxidation were evaluated by $\mathrm{CV}$ and chronoamperometry measurements, with the current densities normalized by Pt loading, as shown in Fig. 5. The typical methanol oxidation peak appeared in the forward sweep at $0.64 \mathrm{~V}$. The oxidation peak in the backward sweep at ca. $0.42 \mathrm{~V}$ represented the removal of incompletely oxidized carbonaceous species formed in the forward sweep [26,27]. The peak current density of Pt/hNCNC reached 342 mA/mgPt@0.64V, which was signifi- 

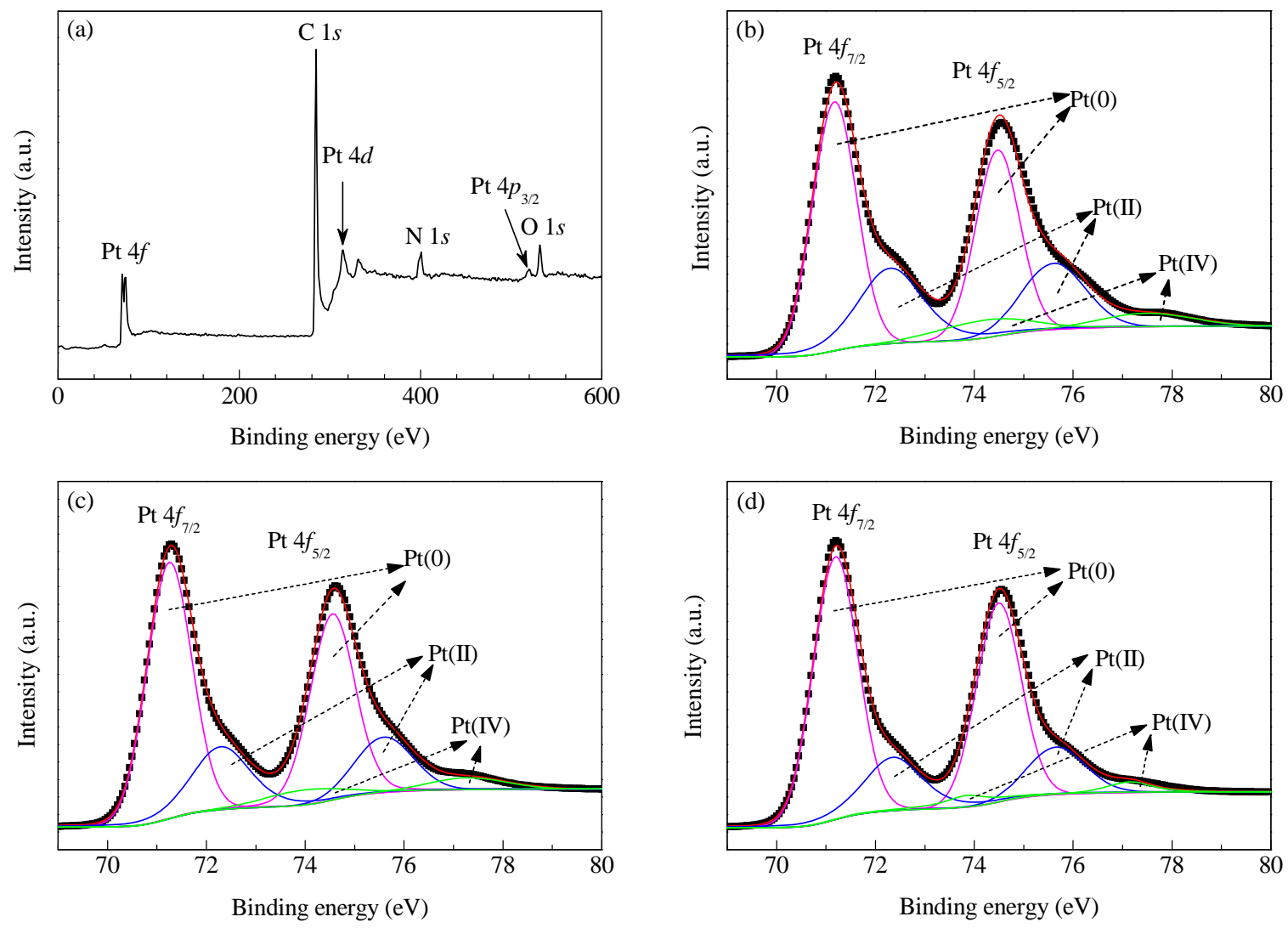

Fig. 3. Broad scan of Pt/hNCNC (a) and Pt 4fXPS spectra of Pt/hNCNC (b), Pt/hCNC (c), and Pt/XC-72 (d).
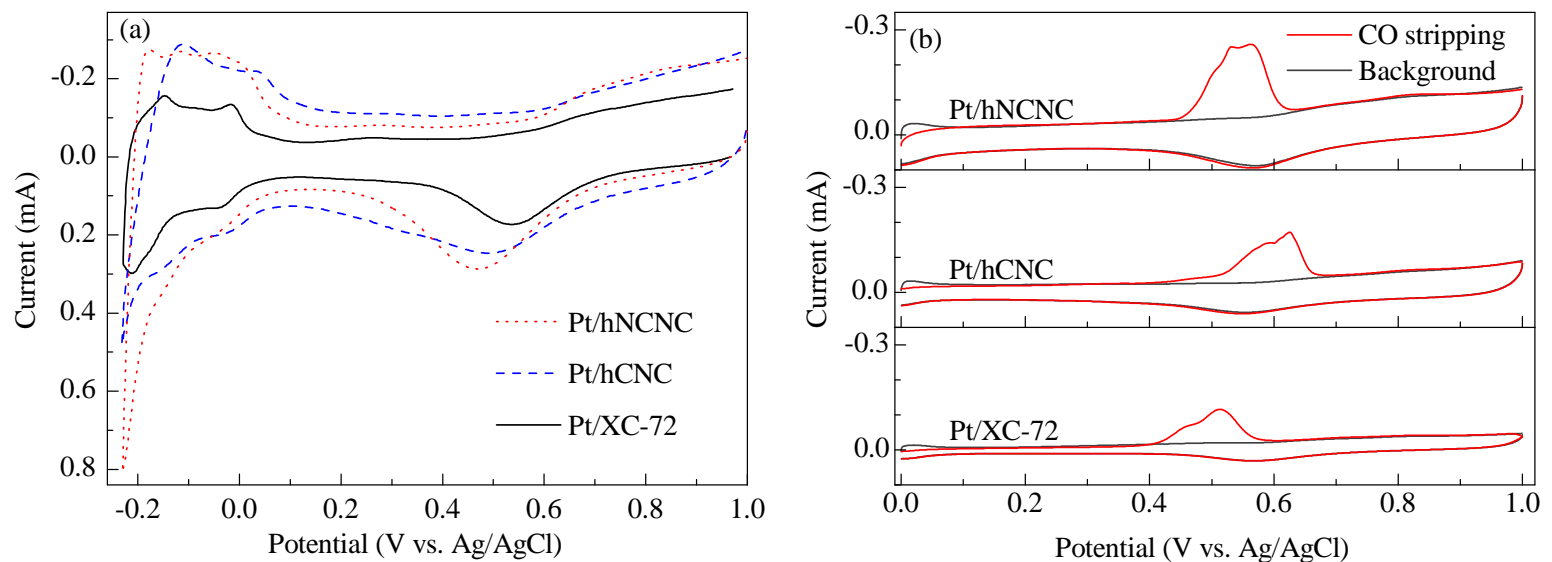

Fig. 4. $\mathrm{ECSA}$ of $\mathrm{Pt} / \mathrm{hNCNC}, \mathrm{Pt} / \mathrm{hCNC}$ and $\mathrm{Pt} / \mathrm{XC}-72$. (a) CV curves of hydrogen adsorption in $\mathrm{N}_{2}$-saturated $0.5 \mathrm{~mol} / \mathrm{L} \mathrm{H}_{2} \mathrm{SO}_{4}$ at scan rate of $50 \mathrm{mV} / \mathrm{s}$; (b) CV curves of CO stripping in $0.5 \mathrm{~mol} / \mathrm{L} \mathrm{H}_{2} \mathrm{SO}_{4}$ at scan rate of $20 \mathrm{mV} / \mathrm{s}$.

cantly larger than $242 \mathrm{~mA} / \mathrm{mg}_{\mathrm{Pt}} @ 0.64 \mathrm{~V}$ of Pt/hCNC and 213 mA/mgre $00.65 \mathrm{~V}$ of Pt/XC-72, in accordance with the relative order of their ECSAs (Fig. 5(a)). Generally, the ratio of the forward to backward sweeping peak current $\left(I_{\mathrm{f}} / \mathrm{I}_{\mathrm{b}}\right)$ is used as an index to evaluate the CO tolerance or the accumulation of carbonaceous species for Pt-based catalysts. A higher $I_{\mathrm{f}} / \mathrm{Ib}_{\mathrm{b}}$ indicates less accumulation of the carbonaceous species and better CO tolerance $[9,28]$. The $I_{\mathrm{f}} / \mathrm{I}_{\mathrm{b}}$ values were $1.09,1.10$ and 1.05 for $\mathrm{Pt} / \mathrm{hNCNC}, \mathrm{Pt} / \mathrm{hCNC}$ and $\mathrm{Pt} / \mathrm{XC}-72$, respectively, indicating a similar CO tolerance of $\mathrm{Pt} / \mathrm{hNCNC}$ and $\mathrm{Pt} / \mathrm{hCNC}$, which was superior to that of $\mathrm{Pt} / \mathrm{XC}-72$. In addition, the chronoamperometry curves of $\mathrm{Pt} / \mathrm{hNCNC}$ and $\mathrm{Pt} / \mathrm{hCNC}$ presented a relatively flat changing trend, reflecting a higher stability than that of Pt/XC-72 (Fig. 5(b)).

These results suggested the hierarchical carbon-based nanocages were a good new support due to the unique network mesostructure. They give a high SSA, good conductivity and rapid diffusion. Nitrogen doping can further regulate the extended and local electronic structure of the carbon support, which favors the high dispersion of the catalytically active spe- 

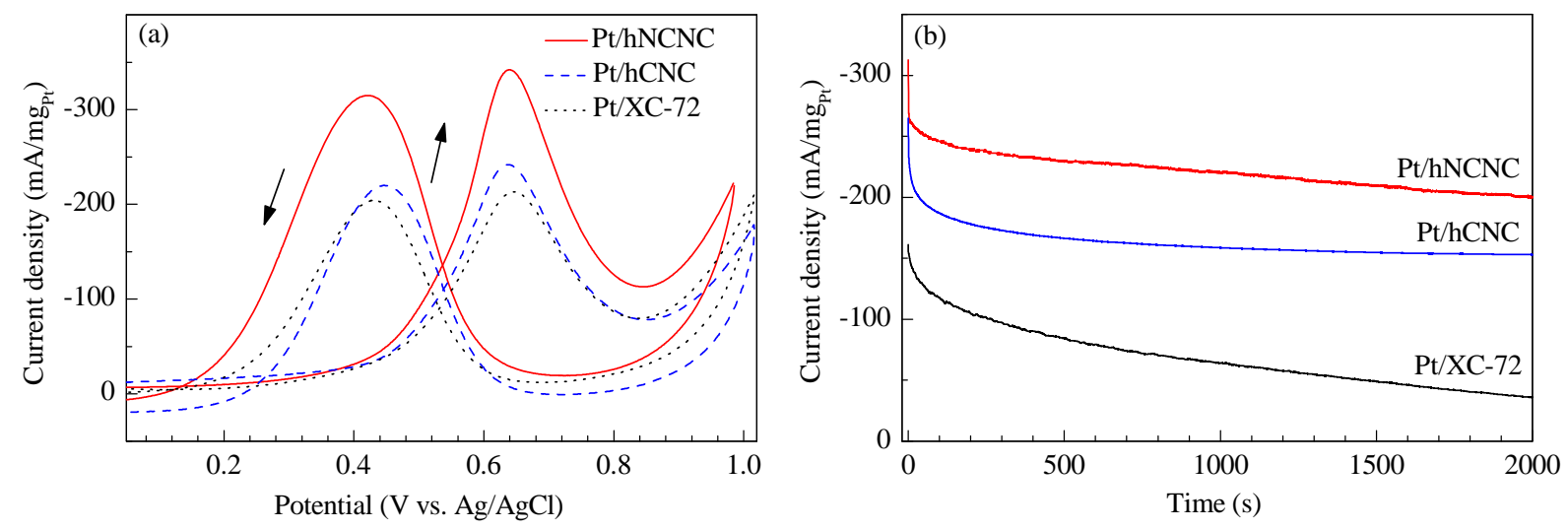

Fig. 5. CV (a) and chronoamperometric (b) curves for Pt/hNCNC, Pt/hCNC, and Pt/XC-72.

cies to achieve a high activity (Figs. 1, 4, and 5). Based on our previous study, from quarternary $\mathrm{N}$-doping, the extra electrons occupy the $\pi^{*}$ orbital and activate the neighboring carbon atoms, while from pyridinic $\mathrm{N}$-doping, the lone pair electrons fill into the $p$-like nonbonding orbits [12]. Both cases would enhance the interaction between hNCNC and $d$ orbital of Pt, thus facilitating the dispersion of Pt nanoparticles and the electrocatalytic oxidation of methanol [13-15].

By making use of the unique advantages of hNCNC, a series of catalysts with high Pt loadings of 30, 40 and $60 \mathrm{wt} \%$ were prepared and characterized as shown in Fig. 6. Even for the high loading up to $60 \mathrm{wt} \%$, the Pt nanoparticles can still be highly and homogenously dispersed on hNCNC without serious agglomeration, with the average size of $5.5 \mathrm{~nm}$, which was in the optimum particle size range of 3-10 $\mathrm{nm}$ for efficient methanol electrooxidation [29] (Fig. 6(a)). Due to the high affinity of nitrogen, nitrogen doping converts the nonpolar covalent bonds of the carbon matrix into polar bonds, which generates
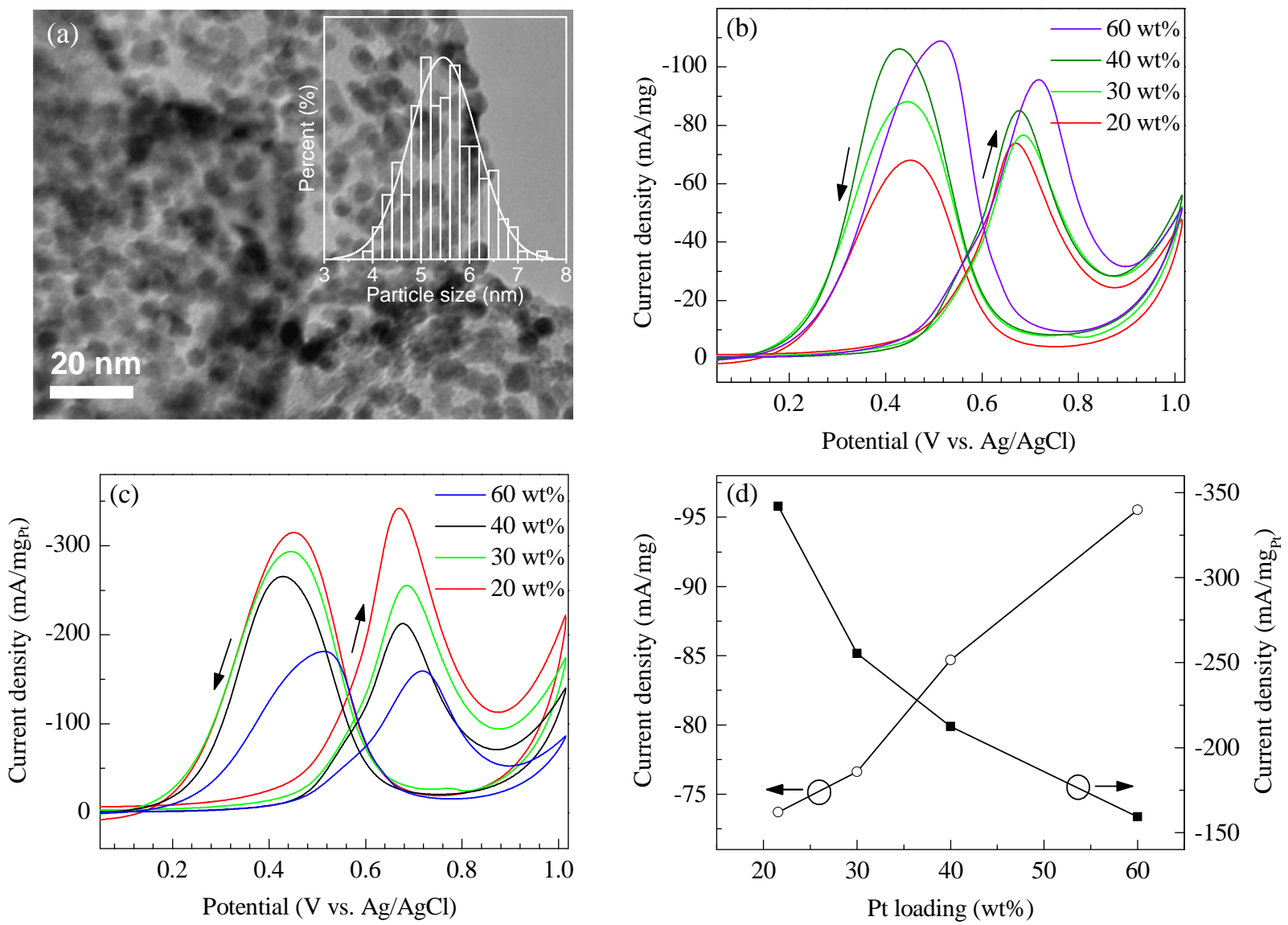

Fig. 6. Activity for methanol oxidation of Pt/NCNC catalysts with Pt loading of 20, 30, 40, and 60 wt\%. (a) TEM image for Pt loading of 60 wt\%; Inset is the particle size histogram from 400 Pt nanoparticles. (b) CV curves normalized by the total mass of catalyst; (c) CV curves normalized by Pt mass only; (d) Plot of forward sweeping peak current vs. Pt loading. Peak currents were normalized by catalyst mass and Pt mass, respectively. 
the functional anchoring sites beneficial for the heavy loading of Pt. With increasing Pt loading from 21.6 to $60 \mathrm{wt} \%$, the peak-current density per unit mass of catalyst gradually increased from 73.7 to $95.6 \mathrm{~mA} / \mathrm{mg}$ by $30 \%$, which is beneficial to achieving a high power density (Fig. 6(b) and (d)). However, the current density per unit mass of Pt species decreased from 342 to $159 \mathrm{~mA} / \mathrm{mg}_{\mathrm{Pt}}$ due to the increased average size (Fig. 6(c) and (d)). Hence, from the viewpoint of increasing power density and decreasing cost, a suitable Pt loading should be optimized for practical applications.

\section{Conclusions}

hNCNC was explored as a new support for Pt nanoparticles. The resulting Pt/hNCNC catalyst exhibited high electrocatalytic performance and stability for methanol oxidation. The hierarchical mesostructure gave a high accessible surface area, good conductivity, and rapid diffusion. Nitrogen doping further increased the functional anchoring sites for Pt, regulated the electronic structure of the carbon matrix, and enhanced the interaction between the support and metal catalyst. At $20 \mathrm{wt} \%$ loading, Pt nanoparticles with the sizes of $3.3 \mathrm{~nm}$ were evenly dispersed on hNCNC without aggregation, which was better than with the control supports of XC-72 and hCNC. The ECSAH and ECSAco of Pt/hNCNC were 45.6 and $51.8 \mathrm{~m}^{2} / \mathrm{g}_{\mathrm{Pt}}$, which were much larger than those of Pt/hCNC and Pt/XC-72, leading to the best electrocatalytic performance of Pt/hNCNC. In addition, hNCNC exhibited a large loading capacity due to the unique structure and abundant nitrogen sites. Small Pt nanoparticles can be loaded on hNCNC up to $60 \mathrm{wt} \%$ without serious agglomeration, and gave higher catalytic currents and higher power density. The hierarchical mesostructure and nitrogen participation of hNCNC can give a general electrode material for energy conversion and storage, e.g., for heterogeneous catalysis, supercapacitors, and lithium air batteries.

\section{Acknowledgments}

The authors acknowledge the supports from Nanjing University. X. F. Jiang would like to highly thank Drs. H. S. Tao, S. J. Jiang, X. T. Qin and P. Y. Zang for their valuable assistances and discussions.

\section{References}

[1] A. S. Arico, S. Srinivasan, V. Antonucci, Fuel Cells, 2001, 1, 133-161.

[2] A. C. Chen, P. Holt-Hindle, Chem. Rev., 2010, 110, 3767-3804.

[3] S. Sharma, B. G. Pollet, J. Power Sources, 2012, 208, 96-119.

[4] T. D. Burchell, Carbon Materials for Advanced Technologie Pergamon, New York, 1999.

[5] H. Wang, C. Wingender, H. Baltruschat, M. Lopez, M. T. Reetz, J. Electroanal. Chem., 2001, 509, 163-169.

[6] S. J. Liao, K. A. Holmes, H. Taprailis, V. I. Birss, J. Am. Chem. Soc., 2006, 128, 3504-3505.

[7] E. S. Steigerwalt, G. A. Deluga, C. M. Lukehart, J. Phys. Chem. B, 2002, 106, 760-766.

[8] T. Hyeon, S. Han, Y. E. Sung, K. W. Park, Y. W. Kim, Angew. Chem. Int. Ed., 2003, 42, 4352-4356.

[9] E. J. Yoo, T. Okata, T. Akita, M. Kohyama, J. Nakamura, I. Honma, Nano Lett., 2009, 9, 2255-2259.

[10] Y. L. Hsin, K. C. Hwang, C. T. Yeh, J. Am. Chem. Soc., 2007, 129, 9999-10010.

[11] R. V. Hull, L. Li, Y. C. Xing, C. C. Chusuei, Chem. Mater., 2006, 18, 1780-1788.

[12] H. Feng, J. Ma, Z. Hu, J. Mater. Chem., 2010, 20, 1702-1708.

[13] B. Yue, Y. W. Ma, H. S. Tao, L. S. Yu, G. Q. Jian, X. Z Wang., X. S. Wang, Y. N. Lu, Z. Hu, J. Mater. Chem., 2008, 18, 1747-1750.

[14] S. J. Jiang, Y. W. Ma, G. Q. Jian, H. S. Tao, X. Z. Wang, Y. N. Fan, Y. N. Lu, Z. Hu, Y. Chen, Adv. Mater., 2009, 21, 4953-4956.

[15] S. J. Jiang, L. Zhu, Y. W. Ma, X. Z. Wang, J. G. Liu, J. M. Zhu, Y. N. Fan, Z. G. Zou, Z. Hu, J. Power Sources, 2010, 195, 7578-7582.

[16] J. Z. Lu, L. J. Yang, B. L. Xu, Q. Wu, D. Zhang, S. J. Yuan, Y. Zhai, X. Z. Wang, Y. N. Fan, Z. Hu, ACS Catal., 2014, 4, 613-621.

[17] T. Sun, Q. Wu, R. C. Che, Y. F. Bu, Y. F. Jiang, Y. Li, L. J. Yang, X. Z. Wang, Z. Hu, ACS Catal., 2015, 5, 1857-1862.

[18] S. Chen, L. W. Wang, Q. Wu, X. Li, Y. Zhao, H. W. Lai, L. J. Yang, T. Sun, Y. Li, X. Z. Wang, Z. Hu, Sci. China Chem., 2015, 58, 180-186.

[19] K. Xie, X. T. Qin, X. Z. Wang, Y. N. Wang, H. S. Tao, Q. Wu, L. J. Yang, Z. Hu, Adv. Mater., 2012, 24, 347-352.

[20] S. Chen, J. Y. Bi, Y. Zhao, L. J. Yang, C. Zhang, Y. W. Ma, Q. Wu, X. Z. Wang, Z. Hu, Adv. Mater., 2012, 24, 5593-5597.

[21] J. Zhao, H. W. Lai, Z. Y. Lyu, Y. F. Jiang, K. Xie, X. Z. Wang, Q. Wu, L. J. Yang, Z. Jin, Y. W. Ma, J. Liu, Z. Hu, Adv. Mater., 2015, 27, 3541-3545.

[22] Y. F. Jiang, L. J. Yang, T. Sun, J. Zhao, Z. Y. Lyu, O. Zhuo, X. Z. Wang, Q. Wu, J. Ma, Z. Hu, ACS Catal., 2015, 5, 6707-6712.

[23] Z. Y. Lyu, D. Xu, L. J. Yang, R. C. Che, R. Feng, J. Zhao, Y. Li, Q. Wu, X.

\section{Graphical Abstract}

Chin. J. Catal., 2016, 37: 1149-1155 doi: 10.1016/S1872-2067(15)61117-2

\section{High-performance Pt catalysts supported on hierarchical nitrogen-doped carbon nanocages for methanol electrooxidation}

Xiangfen Jiang, Xuebin Wang, Liming Shen, Qiang Wu, Yangnian Wang, Yanwen Ma, Xizhang Wang*, Zheng $\mathrm{Hu}^{*}$ Nanjing University, China;

National Institute for Materials Science (NIMS), Japan

Pt nanoparticles were highly dispersed on a new catalyst support of hNCNC, and gave high activity for methanol oxidation due to nitrogen participation and the unique features of hNCNC.

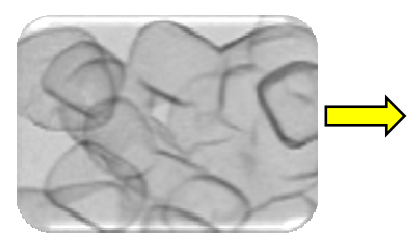

hNCNC

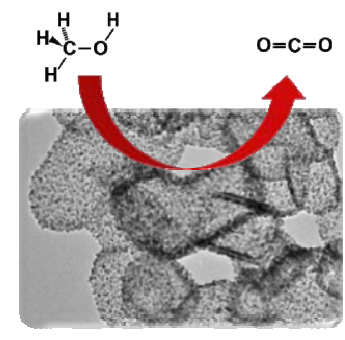

Pt/hNCNC 
Z. Wang, Z. Hu, Nano Energy, 2015, 12, 657-665.

[24] M. Tsuji, M. Kubokawa, R. Yano, N. Miyamae, T. Tsuji, M. S. Jun, S. Hong, S. Lim, S. H. Yoon, I. Mochida, Langmuir, 2007, 23, 387-390.

[25] Z. L. Liu, J. Y. Lee, W. X. Chen, M. Han, L. M. Gan, Langmuir, 2004, 20, 181-187.

[26] Z. Q. Tian, S. P. Jiang, Y. M. Liang, P. K. Shen, J. Phys. Chem. B, 2006,
110, 5343-5350.

[27] Y. H. Lin, X. L. Cui, C. Yen, C. M. Wai, J. Phys. Chem. B, 2005, 109, 14410-14415.

[28] S. Wasmus, W. Vielstich, J. Appl. Electrochem., 1993, 23, 120-124.

[29] K. Bergamaski, A. L. N. Pinheiro, E. Teixeira-Neto, F. C. Nart, J. Phys. Chem. B, 2006, 110, 19271-19279.

\title{
分级结构氮掺杂碳纳米笼担载的铂基高效甲醇氧化电催化剂
}

\author{
蒋湘芬 ${ }^{\mathrm{a}, \mathrm{b}}$, 王学斌, 沈丽明 ${ }^{\mathrm{a}}$, 吴 强 ${ }^{\mathrm{a}}$, 王秧年 ${ }^{\mathrm{a}}$, 马延文 ${ }^{\mathrm{a}}$, 王喜章 ${ }^{\mathrm{a}, *}$, 胡 征, \# \\ a南京大学化学化工学院, 介观化学教育部重点实验室, 江苏南京 210023, 中国 \\ b日本国立材料研究所, 国际纳米结构材料研究中心, 筑波3050044, 日本
}

\begin{abstract}
摘要: 高性能低成本的担载型铂基催化剂是直接甲醇燃料电池 (DMFC) 实用化过程中的一大挑战. 利用高比表面积、高稳 定性、容易负载金属的载体实现 Pt 颗粒的高度分散, 既可提高催化剂的催化性能, 又可提高 Pt 的利用率以降低成本, 是担 载型 Pt 基催化剂实用化的有效途径. 碳材料是一种常用的催化剂载体, 近年来我们课题组发展了一种高性能的碳纳米笼 材料, 并可通过异原子掺杂调变其表面性能, 提高其活性和负载能力. 我们采用原位氧化镁模板法制备氮掺杂碳纳米笼: 以具有多级结构的碱式碳酸镁作为氧化镁模板的前体, 吡啶为碳源和氮源, 经高温热解沉积, 在原位形成的氧化镁模板表 面形成氮掺杂的石墨化碳纳米薄层; 经稀盐酸浸泡并洗涤, 获得高纯度的氮掺杂碳纳米笼. 氮掺杂碳纳米笼具有分等级的 微纳米结构、高导电性、高比表面积和可调变的孔结构, 结合表面氮原子的针钉作用, 氮掺杂碳纳米笼有望成为电化学催 化剂 Pt 的优良载体.

在前期研究基础上, 本文探索多级结构氮掺杂碳纳米笼 (hNCNC) 作为新型载体负载 Pt 的能力, 并评价所构建的负载 型催化剂 Pt/hNCNC 的电催化性能. 通过简便的微波辅助多元醇还原法, 将氯铂酸还原成 Pt 纳米粒子负载于 hNCNC 的 表面. 为了揭示氮掺杂的效应, 我们对比研究了具有相似分级结构但无掺杂的碳纳米笼 (hCNC) 以及商业化活性炭 (Valcan XC-72) 作为载体的情况. 经热重 (TG) 和 X 射线光电子能谱 (XPS) 分析, 三种催化剂 Pt/hNCNC、 Pt/hCNC 和 Pt/XC-72 的负载量均接近理论负载量 (23.1 wt\%), 都主要以金属态存在. 然而, 扫描电子显微镜 (SEM) 和透射电子显微镜 (TEM) 结 果表明, Pt/hNCNC 的 Pt 分散状态优于 Pt/hCNC, 更远优于 Pt/XC-72. Pt/hNCNC 的平均 Pt 粒径最小, 仅约 $3.3 \mathrm{~nm}$. 这种良 好的分散状态主要得益于氮原子掺杂, 高负电性的氮原子改变了局域的表面极性, 有利于 Pt 颗粒的成核, 也有利于固定 Pt 颗粒.
\end{abstract}

由于 hNCNC 对 Pt 的优异分散能力, Pt/hNCNC 表现出高的电化学活性面积. 氢吸附和一氧化碳溶出伏安曲线表明, $\mathrm{Pt} / \mathrm{hNCNC}$ 的电化学活性面积高于 Pt/hCNC 和 Pt/XC-72, 这与显微观察和 X 射线衍射 (XRD) 结果相吻合. Pt/hNCNC 展 现出优异的甲醇电催化氧化活性和高稳定性, 其催化电流明显高于 Pt/hCNC 和 Pt/XC-72, 电流衰减亦慢于 Pt/hCNC 和 Pt/XC-72. hNCNC 的分级微纳米结构有利于孔内传质和电子输运, 从而提高反应速度. hNCNC 的氮掺杂有利于 Pt 在载体 表面的分散, 增强了载体-金属相互作用, 提高了电化学活性面积和催化活性. 为了进一步考察 hNCNC 对 Pt 的负载能力, 本文还考察了高负载量 Pt/hNCNC 的性能. 在负载量高达 $60 \mathrm{wt} \%$ 时, Pt/hNCNC 中的 Pt 颗粒仍无明显聚集, 其甲醇氧化电 流增加了 $30 \%$, 可以有效提高 DMFC 的输出电流密度.

综上可见, hNCNC 可以有效分散并稳定 Pt 颗粒, 从而提高电化学活性面积和甲醇电催化氧化活性, 优于未掺杂的碳纳 米笼和传统碳材料, 展示了 hNCNC 高分散 Pt 颗粒用作 DMFC 的高效阳极催化剂的重要前景, 也表明 hNCNC 有望成为应 用广泛的新型载体.

关键词: 甲醇氧化; 燃料电池; 铂催化剂; 分级结构氮掺杂碳纳米笼; 高性能

收稿日期: 2016-03-30. 接受日期: 2016-04-18. 出版日期: 2016-07-05.

*通讯联系人. 电话/传真: (025)89683696; 电子信箱: wangxzh@nju.edu.cn

\#通讯联系人. 电话/传真: (025)89686015; 电子信箱: zhenghu@nju.edu.cn

基金来源: 国家自然科学基金 (21473089, 51232003, 21373108, 51571110, 21573107); 国家重点基础研究发展计划 (973计划, 2013CB932902); 苏州市科技计划 (ZXG2013025); 常州市科技计划 (CE20130032); 江苏高校优势学科建设工程资助项目.

本文的英文电子版由Elsevier出版社在ScienceDirect上出版(http://www.sciencedirect.com/science/journal/18722067). 